\title{
Legislation
}

\section{THE CALIFORNIA UNEMPLOYMENT INSURANCE LAW}

On June twenty-fifth, 1935, an unemployment insurance law was placed on the statute books of the state of California. ${ }^{1}$ Five states, Wisconsin, Utah, Washington, New York and New Hampshire, had preceded California in this field of legislation and in the later months of 1935 Massachusetts, the District of Columbia, Alabama and Oregon were added to the list of states having unemployment insurance laws. ${ }^{2}$

Unemployment insurance laws must be judged on the basis of coverage, contributions, eligibility for benefits, amount of benefits, length of time for which benefits are given, organization of the insurance fund and administrative organization.

\section{Coverage}

The California law covers only those employees who are employed by employers who are subject to the tax levied by the Federal Social Security Act. ${ }^{3}$ The result of this provision is that an employee is insured against unemployment, only if his employer has employed eight or more employees on solne twenty days during the taxable year, each day being in a different calendar week. ${ }^{4}$ This will exclude many workers from the unemployment insurance scheme, and will have the effect of denying benefits to workers who have a long record of insured employment but who have for a few months worked for an employer employing less than eight workers. Furthermore, it exempts the small employer from paying a share of the cost of unemployment insurance while adding unemployment insurance contributions to the costs of the large employer. This exemption of the small employer and the resulting exclusion of his employee from benefits is an unfortunate and unique contribution which the United States has made to the history of unemployment in-

1 Cal. Stats. 1935, p. 1226. The California act is contingent upon the Federal Social Security Bill Title IX, under which 90 per cent of the contributions under a state act may be credited against the federal tax. Ibid. p. $227, \S 2$.

2 The statutes mentioned in this article are the following: Federal Social Security Act, 49 STAT. (1935) 626, 639-645, 42 U.S. C. A. (1935 Supp.) §§501-503, 1101-1110; Dist. of Col., Public Acts 1935, 74th Cong. No. 386; Mass. Laws 1935, c. 479 , c. $151 \mathrm{a}$; N. H. Laws 1935 , c. 99 ; N. Y. Laws 1935, c. 468; Ore. Laws 1935 , Spec. Sess., c. 70; Utah Laws 1935, H. B. No. 86; Wash. Laws 1935, c. 145; Wis. Stats. 1935 , c. 108.

3 Cal. Stats. 1935 , p. $1228, \S \S 8,9 ; 49$ STAт. (1935) 639, 42 U.S.C.A. (1935 Supp.) $\$ \S 1101-1110$.

449 Stat. (1935) 642, 42 U.S. C. A. (1935 Supp.) \& 1107; Cal. Stats. 1935, c. 352 , p. 1226 . The California law provides that if the definition of employer given above should be declared invalid, coverage would be extended to persons, firms, partnerships, associations, trusts or estates, joint stock companies or corporations, employing four or more workers on some thirteen days in the calendar year, each day being in a different calendar week. Cal. Stats. 1935, p. 1228, \& 9(a). 
surance. There is no justification for this exclusion. Not all of the laws in the United States have adopted such a broad exclusion as has California. One law, that of the District of Columbia, makes no exclusion on the basis of the number of employees. New Hampshire, New York, Oregon, Utah and Washington include those who employ four or more and Alabama, Massachusetts and Wisconsin, like California extend their coverage only to those who are taxed under the Social Security Act, that is, who employ eight or more persons. ${ }^{5}$

Workers in certain employments are also excluded under the California and Federal acts. ${ }^{6}$ They are agricultural laborers, domestic servants in private homes, officers or crews of vessels, individuals employed in the service of a son, daughter or spouse and children under twentyone years of age in the employ of their father or mother, employees of the United States Government or one of its instrumentalities, employees of a state or one of the political subdivisions thereof, employees of a corporation, community chest, fund, or foundation, organized and operated exclusively for religious, charitable, scientific, literary, or educational purposes, or for the prevention of cruelty to children or animals and operated on a non-profit basis.

The exclusion of agricultural laborers and domestic servants is in part a carry-over from our workmen's compensation legislation and in part the result of a belief that if the coverage were extended to these occupations insurmountable administrative difficulties would arise. To deny the protection of unemployment insurance to a worker merely because he has chosen a particular occupation is unjust. Furthermore the administrative difficulties have proved not to be insuperable in the few European countries which lave tried the experiment of including agricultural and domestic labor. There is, perhaps, some justification on administrative grounds for excluding these workers during the early years of unemployment insurance legislation. Even in the mitial period of unemployment msurance, however, workers in excluded occupations who are employed in large establishments might be included without undue administrative difficulties. New York is the one state in which domestic servants are covered, if four or more are employed.

Ships' crews are excluded because they are not subject to state jurisdiction; relatives, because of the difficulty of determining whether they are bona fide employees; governmental employees, because a state may not tax a federal employee nor the federal government a state employee. The exclusion of employees of non-profit organizations was the result of a powerful lobby when the Social Security Bill was being

5 Ala. Laws 1935, Act 447, § 2(f); D. C., Public Acts 1935, 74th Cong. No. 386, § 3(a) ; Mass. Laws 1935, c. 479, ch. 51A, § 1(c); N. H. Laws 1935, c. 99, §1(v); N. X. Laws 1935 , c. $468, \$ 502$ (3); Ore. Laws 1935, c. 70, $\$ 2$ (d); Utah Laws 1935, H. B. No. 86, §3; Wash. Laws 1935, c. 145, § 3 (6); Wis. Stats. 1933, $\S 108.02$ (d).

649 Stat. (1935) 642, 42 U.S. C.A. (1935 Supp.) § 1107 (c); Cal. Stats. 1935, p. $1227, \S 7$. 
drafted. There is no good reason why the workers in these organizations should be denied the protection of unemployment insurance.

\section{CONTRIBUTIONS}

The California unemployment insurance system is financed by contributions from both employers and employees. The contributions are graduated in accordance with the following scale and are based on the wage paid to each employee who is covered by the scheme. Employer Contribution Employee Contribution
per cent of wage

1936

1937 per cent of wage

1938 and after

$\begin{array}{rr}.9 & .5 \\ 1.8 & 1.0 \\ 2.7 & 1.0\end{array}$

Although the above rates of contribution are those which the law requires, the Unemployment Reserves Commission has ruled that employees for the first year shall contribute only .45 per cent of their wages. This is in order to comply with the provisions of the law that employees shall not contribute more than half of the amount contributed by the employer. ${ }^{\circ}$

Beginning in 1941 contribution rates may be reduced under a merit rating plan which is shown in the following table. ${ }^{10}$

$\begin{array}{lc}\text { Reserve for preceding } 3 \text { or } 5 \text { years } & \\ \text { whichever is higher . . } & \text { Employer Contribution } \\ \text { Per cent of payroll } & \text { Per cent of wage } \\ 8 \text { but less than } 10 \% & 2.5 \\ 10 \text { but less than } 12 \% & 2.0 \\ 12 \text { but less than } 15 \% & 1.5 \\ 15 \% \text { or more } & 1.0\end{array}$

Similar schemes of merit rating have been adopted in all of the unemployment insurance laws in the United States with the exception of New York. The theory on which these provisions have been based is that unemployment insurance may serve as a stimulus to prevent unemployment. This theory is of doubtful validity, inasmuch as the employer already has, in the profit motive, the strongest possible incentive to check preventable unemployment. Unemployment is largely due to causes beyond the control of the individual employer, and no amount of incentive can result in its prevention by him. The result of

7 Cal. Stats. 1935 , pp. $1232,1234, \S \S 38,44$. Employee contributions are to be withheld from wages by employer.

8 The employers' contributions were placed at these amounts, so that advantage could be taken of the entire credit allowance under the Federal Social Security Act. This Act places a tax on all wages paid by employers. The tax is 1 per cent in 1936, 2 per cent in 1937, and 3 per cent thereafter. If the state passes an unemployment insurance law which meets the approval of the Social Security Commission, nimety per cent of the tax will be remitted.

9 Bulletin No. 1, Temporary Rules and Procedure Issued by the Unemployment Reserves Commission, Jan. 1, 1936, p. 1.

10 Cal. Stats. 1935, p. 1233, \$39. Employee's contribution may never be more than half that of the employer. Thus when the employer's contribution is reduced to 1.5 per cent the employee's contribution must also be reduced. 
the merit rating plan will be to reduce contributions only from employers in industries which are by their nature stable.

Justification for exacting lower contributions from the more stable plants can be found if unemployment insurance is to be regarded in the same light as commercial insurance, that is to say, the better risks may be said to be entitled to a lower rate of premium than the poorer risks. If, however, unemployment insurance is viewed as a method of meeting the social problem of unemployment, it may be considered more analagous to taxation in which the exaction is made with respect to ability to pay and social need rather than on the basis of fine distinctions as to responsibility for the need which is to be met. The primary purpose of unemployment insurance is, in the writer's opinion, to provide security to the worker during periods of unemployment. This aim will be more adequately promoted if the fund is enlarged by equal contributions from all employers.

In requiring employee as well as employer contributions, California has followed the plan universally adopted in European countries. Four of the United States Laws, those of the District of Columbia, New York, Utah, and Wisconsin, require no contribution from the en1ployee. ${ }^{11}$ There has been considerable argument as to whether the employee should carry part of the burden of the cost. It has been argued that, in any case, the worker bears a considerable part of the cost of unemployment even though he is covered by unemployment insurance. Unemployment insurance benefits never equal wage, there is always a "waiting period" before benefits can be drawn and there will always be a tendency on the part of employers to pass on the costs of uneinployment insurance to the public generally, including the workers, in the form of higher prices. These are good arguments for requiring contributions only from the employer. There are, however, two reasons for requiring employee contributions. In the first place, if the employee contributes, he may find himself possessed of more power in the administration of the scheine; and in the second place, a broader base for contributions may increase the size of the fund and thus inake possible more generous benefits. ${ }^{12}$

There has been inuch heated discussion in the United States as to whether contributions should be pooled in one fund, or a separate fund be established for each employer, from which alone his employees can draw benefits. Fortunately, California along with seven other states adopted the pooled fund plan. ${ }^{13}$ Individual plant reserves, violate the insurance principle of distribution of risk, and place the individual worker in an insecure position when through no fault of his own he has

11 D. C., Public Acts 1935, 74th Cong., No. 386, \& 19 (a) ; N. Y. Laws 1935, c. 468 , § 517; Utah Laws 1935 , H. B. No. $87, \& 25$; Wis. Stats. 1935 , § 108.11.

12 It is in general true that those laws which require contributions froun employers provide benefits for longer periods of time.

13 Cal. Stats. 1935 , p. 1233 , $\$ 39,40$. For deviations from this principle, see infra note 14 . 
been working for an employer whose reserve fund has been depleted. Furthermore, the general consensus of opmion is that this scheme will not have much success as a stabilizer of employment, which is one of its main assumptions.

As has already been pointed out, the California act, provides for merit rating beginning in 1941 . This is a compromise between the individual plant reserve and a straight pooled fund.

Two more provisions of the California act should be mentioned at this point since they are related to the security of the fund from which benefits are to be paid. The Unemployment Reserves Commission is given authority to exempt from the scheme employers having guaranteed employment plans or private unemployment benefit plans. A guaranteed employment plan may be exempted from contributions to the fund, if workers who have been employed for eight weeks are guaranteed certain specified weeks of work, and if the Commission is satisfied that the employer can and will make good his guarantee. ${ }^{14}$ Private unemployment benefit plans may be exempted if they (1) make eligible for benefits at least the employees who would be eligible under the compulsory act; (2) if the proportion of the benefits to be financed by the employer is equal to or greater than that which is provided under the compulsory act; (3) if the scheme is, on the whole, as beneficial to employees as is the compulsory plan. In exempting such schemes the Commission is given the power to require such security as it may deem sufficient.15

Both of these exemptions may affect the degree of security provided by the unemployment insurance law. It is likely that the good risks will "contract out" of the general scheme, thus interfering with the broad distribution of the risk of unemployment. Furthermore, employees in the establishments which have contracted out will not have the protection of the pooled fund. Apparently these provisions were put in the bill as the result of an employers' lobby, and of the provision of the Social Security Act which allows employers making payments on a merit rating basis or having guaranteed employment or private unemployment benefit plans, to credit against the Federal tax an amount equal to the highest contribution rate paid by any employer in the state. ${ }^{16}$

14 Cal. Stats. 1935 , p. 1234, \& 47. The Federal Social Security Act requires that in order to receive credit for the tax, the guaranteed employment account must not be less than $71 / 2$ per cent of the annual wage bill and the guarantee must have heen fulfilled in the preceding year. 49 STAT. (1935) 644, 42 U.S.C.A. (1935 Supp.) $\S 1110$.

15 Cal. Stats. 1935, p. $1235, \$ \S 48,49$. The Federal Social Security Act requires that in order to receive credit for the tax, compensation must have been paid throughout the preceding year, the account must be not less than five times the largest amount of compensation paid within any one of three preceding years, and the account inust not he less than $71 / 2$ per cent of the total wages paid hy the employer. 49 StAT. (1935) 644, 42 U.S.C.A. (1935 Supp.) § 1110.

1649 STat. (1935) 643, 42 U. S. C. A. (1935 Supp.) § 1109. 
The Social Security Act requires that all money paid into a state unemployment imsurance fund shall be transmitted to the Secretary of the United States Treasury, to be deposited in the Unemployment Trust Fund created under the Act. ${ }^{17}$ The Secretary of the Treasury is given the responsibility of investing such portion of the Unemployment Trust Fund as is not, in his judgment, required to meet current withdrawals. The inoney must be invested in interest bearing obligations of the Umited States government or in obligations guaranteed both as to principal and interest by the United States. ${ }^{18}$ A separate book-keeping account is to be kept of the funds of each state and payments made on requisition from the state agency which is administering the unemployment insurance scheme. ${ }^{19}$

The California act has complied with the federal requirement, in providing that all contributions paid under the scheme shall be deposited in the Unemployment Trust Fund of the United States. ${ }^{20}$

The deposit of the Unemployment Insurance funds with the United States Treasury not only takes the control of the funds out of state politics, but makes it possible to relate the investment of the funds to the need for expansion or contraction of credit in the country as a whole. $^{21}$

\section{QUALIFICATIONS FOR RECEIPT OF BENEFITS}

In order to qualify for the receipt of benefits, the worker must meet certain conditions. The California act requires that, in order to be eligible for benefits, the worker must have been employed in the state, presumably in an insured employment, for twenty-six weeks in the year preceding unemployment and must have been a resident of the state for one year immediately preceding the beginning of his unemployment. $^{22}$ The other state laws have somewhat similar requirements regarding the number of weeks of previous employment. The purpose of these provisions is to make certain that the unemployed person has been a bona fide member of the labor supply and to avoid the excessive costs of grantimg benefits to workers who have been in insured employment for only a few weeks. California is unique in her provision requiring residence in the state for a year.

Other requirements of the California act, are that the employee must be physically able to work and available for work, ${ }^{23}$ that he must file notice of his unemployment and make claim for benefits at the

\footnotetext{
1749 Stat. (1935) 640, 42 U.S. C. A. (1935 Supp.) § 1103 (a).

1849 STAT. (1935) 640, 42 U.S. C.A. (1935 Supp.) $\$ 1104$ (b).

1949 STAT. (1935) 640, 42 U.S. C.A. (1935 Supp.) $\$ 1103$ (b).

20 Cal. Stats. 1935, p. 1230, § 22.

21 For a discussion of the investunent of Reserve Funds see Hansen, Murray, Stevenson, Stewart, Progran for Unenoployment Insurance and Relief in THE UNTTED STATES (1934) pp. 166-195.

22 Cal. Stats. 1935, p. 1238, \$56 (d).

23 Ibid. p. 1236, § 51.
} 
district employment office. ${ }^{24}$ In order to remain eligible for benefits, the worker must accept "suitable" employment when offered. ${ }^{25}$ Suitable employment ${ }^{26}$ is defined as employment for which the employee is reasonably fitted, which is in the vicinity of the employee's residence or last employment, and which either gives him wages at least equal to his weekly benefit for total unemployment or provides him work for at least half the number of hours normally worked at full time in the occupation or establishment. Employment is not deemed suitable if the vacancy is due to a strike or lockout or other labor dispute; if as a condition of employment the employee is required to join a company union or to resign from or refrain from joining a bona fide labor organization; or if the wages, hours or other conditions of the work offered are substantially less favorable than those which prevail for similar work in the locality. ${ }^{27}$ In addition to the foregoing provisions whose purpose is to prevent employers froin using the unemployment insurance plan as a weapon agamst organized labor, or to depress working conditions, the California act, in order to prevent the unemployment insurance fund from bemg used as a strike fund, denies benefits if the unemployment is due to a strike, lockout, or other labor dispute while such dispute is in active progress in the establishment in which the worker was employed. ${ }^{28}$

\section{、 Waiting Period}

An employee does not receive unemployment insurance benefits immediately upon becoming unemployed, even though he meets the qualifying conditions. The California act provides for a waiting period of four weeks in 1938 and 1939 and three weeks thereafter. ${ }^{20}$ The act states that not more than the total time of the waiting period per employer shall be required of any employee in any twelve consecutive months. It is impossible to hazard a guess as to whether the phrase per employer was inserted in this section knowingly or whether it was a typographical error and the intention was to require only one waiting period of the unemployed worker each year. It seems inevitable that the law as it now stands will be interpreted so that every time a worker loses his job, an additional waiting period will be required, unless he is fortunate enough to have worked for the same employer within a year. Thus the unemployed worker who has been employed by a number of employers will spend most of his time "waiting" for benefits.

The purpose of the waiting period is to allow time for investigation

24 Ibid. p. I240, $\$ \S 65,66$.

25 Ibid. p. 1238, \& 56 (c).

26 Ibid. p. 1229, \$13.

2749 Stat. (1935) 640, 42 U.S.C.A. (1935 Supp.) \&1103 (a) (5). These conditions must he met if credit is to be given for the tax under the Federal Act.

28 Cal. Stats. 1935 , p. $1238, \$ 56$ (a). Similar provisions are found in all of the unemployment insurance laws in the United States.

29 Ibid. p. 1237,854 . , 
of claims, to discourage malingering, to save the administrative cost in the payment of vast numbers of small claims and to avoid the depletion of the funds by paying benefits for periods of unemployment of very short duration. It would seem that all of these purposes would be served by a waiting period shorter than four or even three weeks. In view of the meagerness of most wage earners' incoines, even in periods of relative prosperity, a waiting period of one or at most two weeks would Inore nearly meet a standard of adequate protection.

The California bill doubles the waiting period if the worker has lost his employment through misconduct, or if he has voluntarily left his employment. ${ }^{30}$ This is in the nature of a penalty. To double the waiting period for this purpose seems adequate; to increase it more than this, which is done in some of the state laws, appears unjustified.

\section{Benefits}

The Cahfornia law grants benefits for total unemployment and for partial unemployment. The worker who is totally unemployed is given a benefit equal to fifty per cent of his average weekly wage, but there is a maximum of $\$ 15.00$ and a minimum of $\$ 7.00$ a week. ${ }^{31}$ California has followed the universal practice of the states in fixing benefits at a percentage of wages rather than granting a flat rate which is the same for all. A benefit which is a per cent of wage is preferable to a flat rate benefit, because it bears a relation to the standard of living of the worker. Moreover the amount of the benefit is difficult to determme if it is to be a flat rate. In order to prevent the benefit from too closely approximating the wage, a flat rate would necessarily have to be considerably lower than the wage of lowest paid workers. This would result in very inadequate protection for the higher paid workers.

The benefit granted under the California Unemployment Insurance Law is to be criticized for being too low, and also because it is not a higher percentage of the wage of the lower paid than of the higher paid worker, except in so far as the maximum and minimum affect the very low paid worker and the worker earning more than $\$ 30.00$ a week. A more equitable scale would be one which would grant progressively higher benefits to lower paid workers. Since the benefit must be considerably less than wages and since, in any case, wages are not related to family needs, there should also be an additional benefit for dependents. It is suggested that five per cent be added to the benefit for each dependent with a inaximum of seventy-five per cent of wage and a maximnm amount of $\$ 20.00$ a week. The District of Columbia law is the only law in the United States which provides benefits for depen-

30 Ibid. p. 1237, §55.

31 Ibid. p. 1238, $\$ 58$. With the exception of the District of Columbia which grants forty per cent to a single person and five per cent additional for each dependent, there is complete unanimity among all of the laws in the United States as to the per cent of wage given as benefits and great similarity as to maximum and minimum benefits. Public Acts, 1935, 74th Cong., No. 386, $\$ 8$ (a) 
dents..$^{32}$ In order to simplify administration, wage classes should be set up and the benefit for those who fall into each wage class should be based on an assumed wage. Such a scale of benefits is shown in the following table. ${ }^{33}$

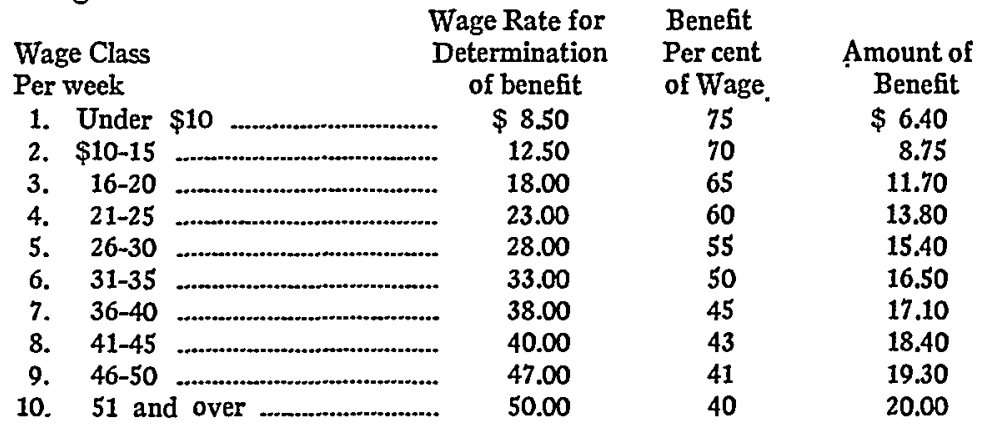

Another criticism of the California act may be that since contributions are made on the entire wage, and the maximum benefit granted is $\$ 15.00$ a week, a worker may have contributed on a very high wage and receive in benefits a very small per cent of his wage. This means that the higher paid workers carry a heavier share of the cost than those in the lower brackets. This result may be justified on the ground that the contribution will not be irksome to the worker with a high income and that it serves to enlarge the fund and make possible the payment of more adequate benefits to the lower paid workers. Such a theory of general social welfare may, however, not be acceptable to those workers who contribute and receive little in return, and there may be attempts to change the law in this respect. Some of the State laws have adopted a scheme which makes for a somewhat closer relation between benefits and contributions. This has been accomplished by excluding from the scheme, workers earning above a certain amount. ${ }^{34}$ A preferable provision would be one like the provision of the Federal Old Age Annuity scheme, which for the purposes of the act, defines wage as only the amount earned up to $\$ 3000 .^{35}$ There would, however, be no good reason for adopting such a restriction as long as the employer is taxed on all wages under the Social Security Act.

In addition to benefits for total unemployment, the California act makes eligible for benefits, workers who are partially unemployed. Partial unemployment is defined as any temporary reduction in working hours below the normal working hours which results in loss of wages.

32 Ibid.

33 For a similar but somewhat lower scale of benefits, see Douglas, Standards OF UNEMTPLOYMENT INSURANCE (1933) p. 89.

34 N. Y. Laws 1935, c. $468, \S 502$ (2) and N. H. Laws 1935, c. $99, \S 1$ (iv) exclude other than manual laborers who earn more than $\$ 2500$ a year.

Mass. Laws 1935 , c. $479, \$ 1$ (b) excludes all who earn $\$ 2500$ a year or more, and Utah Laws $1935, \mathrm{H}$. B. No. 86, $\$ 3$ (e) excludes all who earn $\$ 2000$ a year or more. 3549 StaT. (1935) 639, 42 U.S.C.A. (1935 Supp.) § 1011 (a). 
The normal working hours are computed as the hours per week most commonly worked in the preceding three years. ${ }^{36}$ The benefit for partial unemployment is the difference between the employee's actual wages for the week and the weekly benefit to which he would be entitled if totally unemployed. ${ }^{37}$ In this provision, the California law follows the theory of the New Hampshire and Wisconsin statutes, that in order to qualify for benefits, the worker's wage for partial employment must be less than the benefit for total unemployment. Some of the laws, on the other hand, have attempted to provide a stimulus to the worker to keep his job, by granting him benefits of one or two dollars even though his earnings for partial employment equal the benefit for total unemployment. It would seem that this plan is to be preferred since not only does the worker keep up his morale by working, but he is more likely to be given precedence when full time work is available.

Part time workers are also eligible to receive unemployment insurance benefits. A part time worker is defined as one, who for reasons personal to himself, is unable or unwilling to work the usual full time, and who customarily works less than the full time prevailing in his place of employment and who registers as a short time worker. The Commission is given the responsibility of fixing the benefits to be paid to these workers. A different qualifying period of einployment and different maximum and minimum benefits may be set up..$^{38}$ Although four states ${ }^{39}$ do not grant benefits to part time employees, it would seem that California has been wise in this provision. The worker who is regularly einployed part time is probably dependent upon his earnings for part of his livelihood and should have the protection of unemployment insurance benefits. The possible danger of bringing within the scheme workers who are not bona fide members of the labor supply can be avoided by the special rules and regulations of the comnission.

The California law makes no special provision for seasonal unemployment. The provision that workers are covered if they work for an einployer who employs eight or more workers for as long as twenty weeks in a year, will of course affect seasonal workers, as will the exclusion of agricultural workers and the provision that the worker must have been employed in an insurable employment for twenty-six weeks in the year preceding his unemployment.

The problem is, whether workers in seasonal industries should be entirely excluded from the uneinployment insurance scheme, whether they should be included and compensated for unemployment which occurs within the usual season of employment, or whether they should be included and allowed benefits for all unemployment, including seasonal unemployment. It is generally agreed that the unemployment

36 Cal. Stats. 1935, p. 1229, § 14.

37 Ibid. p. 1239, § 58 (b).

38 Ibid. p. 1239, \$ 60.

39 Alabama, District of Columbia, Utah and Washington. 
insurance fund cannot stand the drain of payments for recurring periods of seasonal unemployment. On the other hand, workers engaged in seasonal industries should be protected against unemployment which occurs within the period during which they might normally expect to be occupied. Such payments would not constitute an abnormal drain on the fund. Above all things, it is necessary to guard against requiring contributions from workers who in the normal course of events can never receive unemployment benefits.

The California act, by requiring contributions from all workers who are employed by employers of eight or more for a period of twenty weeks or more in a year, exacts contributions from workers in seasonal industries in which eight or more persons are employed for twenty weeks or more a year. Furthermore, unless the individual worker is himself employed for twenty-six weeks or more he can never receive benefits. The only practical solution seems to be to allow the Commission to make special rules and regulations governing contributions from and payments to workers engaged in seasonal industries. Some of the state laws have included such a provision.

The length of time during which benefits are paid is of extreme importance. Under the California act, one week's benefit is allowed for four weeks' contribution, with a maximum of thirteen weeks' benefit in one year if less than 104 contributions have been made and a maximum of twenty weeks' benefit in one year if 104 or more contributions have been made. ${ }^{40}$ For instance if a worker has worked steadily for ten years and has made 520 contributions to the unemployment insurance fund, he is entitled to 130 weeks of benefit. He may draw twenty weeks of benefit in the first year and twenty weeks of benefit in every year thereafter, until he has drawn benefits for 130 weeks, if he has been employed for twenty-six weeks in the preceding year. If, however, he has no employment in the second year he is not entitled to any benefits. The requirement of all the unemployment insurance laws in the United States, that an unemployed person inust have had a given number of weeks of employment in the year preceding his unemployment is to restrict benefits to bona fide members of the labor supply and to exclude from benefits those workers who are unable to find any work. There is some injustice in this, in that the worker who has had many years of steady employment, may be able only to draw benefits during part of one year. It has, however, been found in England and in other countries of Europe that allowing workers to draw benefits on the basis of employment several years in the past may load up the scheme with unemployables and may so deplete the fund as to defeat the primary purpose of unemployment insurance which is to give security to the nore or less regularly employed popnlation.

In common with all of the other state laws, there is found in the California act a general restriction on the payment of unemployment

40 Cal. Stats. 1935, p. 1238, § 58 (c). 
benefits. If the Commission determines that the condition of the fund is such that, within six months, it will be unable to pay estimated benefit liabilities in full, it may reduce or cease payment of benefits. ${ }^{41}$ Since the actuarial groundwork of uneinployment insurance legislation has not been very carefully laid, this is probably an essential provision. It should, however, be possible in the future to deterinime in advance that a given contribution will provide stated benefits for definite periods of time.

Some protection must be given the employee in cases in which he has reason to doubt the validity of a denial of his benefit, or if he has reason to question either the amount of his benefit or the length of time for which benefits are granted to him. The California law provides that an employee may appeal directly to the Commission. The Cominission is given the power to prescribe the marmer of hearing such appeals, and if in their opinion the appeal was made in bad faith, a penalty not exceeding ten per cent of the amount finally awarded may be deducted. ${ }^{42}$

\section{ADMINISTRATION}

The California Unemployment Insurance Law is to be administered by a Department of Employment, the governing body of which is the Unemployment Reserves Commission. This Commission is made up of five persons appointed by the governor. Two of the commissioners must represent labor, one a large employer, one a small einployer and one the public. The terms of office of the commissioners are overlapping, so that except for the first appointments their terms of office will not coincide with that of the governor. The commissioners are not paid a salary, but they are paid ten dollars a day during their actual performance of duty with a inaximum of $\$ 1200$ a year. The Commission is given the power to appoint its executive officer, who shall also be the Director of the Department of Employment. He is not subject to the Civil Service Laws. All other employees of the Commission are, however, to be subject to the Civil Service Laws. ${ }^{43}$. The costs of administering the act are to be paid out of the unemployment administration fund, ${ }^{44}$ which is to be provided out of the tax to the federal government.45

On July 1, 1936, the Division of the State Einployment Agencies of the Departinent of Industrial Relations is to be taken over by the Department of Employment. ${ }^{46}$ In order to facilitate the administration of the unemployment insurance act, the Unemployment Reserves

41 Ibid. p. $1240, \S 63$.

42 Ibid. p. 1240, $\S \S 69-71$.

43 Ibid. pp. 1241, 1242, §§ 77-88.

44 Ibid. p. 1230, \& 23.

45 The Federal Act provides for payments to states of sums necessary for the proper administration of the unemployment insurance laws. 49 STAT. (1935) 626, 42 U.S. C. A. (1935 Supp.) §502.

${ }^{46}$ Cal. Stats. 1935, p. 1243, § 93. 
Commission is given the power to create unemployment districts, to establish a system of public employment exchanges and to make rules for the registration of unemployed persons. ${ }^{47}$ It is fortunate that the state employment agencies are to become a part of the unemployment insurance organization since registration and placement are of prime importance to prevent malmgering and to bring about reemployment as rapidly as possible.

The Unemployment Reserves Commission is given the power to issue rules and regulations which are necessary for the interpretation and enforcement of the act, and it is required to keep such records as are necessary for the proper administration of the act. ${ }^{48}$ It is definitely stated in the act that every employer must keep a record of (a) all his employees, (b) the hours worked by each employee, and (c) the wages paid to each employee.

The fact that the law requires the employer to keep the records above mentioned carries the implication that the imformation recorded is for the purpose of the proper administration of the act and is to be turned over to the Unemployment Reserves Commission. The Commission under its temporary regulations requires the employer to furnish information only as to his total number of employees, total wages paid and total employer's and employee's contribution. ${ }^{40}$ In addition a notice of termination ${ }^{50}$ must be given to the employee and to the Commission when a worker leaves his employment. The notice of termination merely indicates the date of employment, the date of termination, the reason for termination, the average weekly wage and the number of weeks during the previous 104 weeks for which contributions were made.

The temporary admmistrative procedure set up by the Unemployment Reserves Commission provides no individual contmuous record of an employee's contributions or of his employer's contribution in his behalf and thus no authentic record of the record of the worker's right to benefits. The worker must take his employer's word for the validity of the information on the termination notice since the worker's own knowledge must be based on his memory in regard to his weeks of employment and his wage. Furthermore, the Commission will have no individual record of contributions since the only information required from employers is as to total wages paid by employers to their employees. For the proper administration of an unemployment insurance act, there must be an individual record for every employee. This could be accomplished by requiring the employer to furnish the information to the Commission. A better method would, however, be the stamp

47 Ibid. p. 1242, \& 92 .

48 Ibid. $\$ 90$.

49 Bulletin No. 2, Rules and Procedure Issued by the Unemployment Reserves Commission-effective January 1, 1936-p. 3 .

50 Bulletin No. 1, Rules and Procedure Issued by the Unemployment Reserves Commission-effective January 1, 1936-p. 3. 
book scheme employed in England. Under such a plan every worker would have a book in which each week would be placed stamps equalling the amount of his and his employer's contribution. The worker would thus be able at all times to determine his status in regard to contributions and benefits and an occasional inspection of these books by the administrative authority would be all that would be necessary. This would be a much less cumbersome and less expensive method of administermg the uneinployment insurance scheme than would be one which required imdividual reports to the administrative authority from every employer for each employee.

In order to make it possible to enforce a law, penalties must be exacted from those who do not comply. The California law provides that if an employer defaults in any payment required of him, he shall become additionally liable for interest on such payments at the rate of twelve per cent per annum, and if necessary, civil action may be taken by the commission against the defaulting employer..$^{51}$ It is furthermore made a misdemeanor for anyone to make false statements to obtain any benefits or payment under the act, for an employer to make greater deductions from wages than is required under the act, to fail to open his employment record to the inspection of the commission, or to fail to appear at hearmgs or to produce papers required by the commission. 52

California is to be congratulated on being one of the states in the vanguard of unemployment msurance legislation in the United States. The law has many imperfections, the most serious of which are the exclusion of workers in small establishments, and the deviation from a straight pooled unemployment insurance fund, and the fact that the unemployed worker will, in many cases, be forced to "wait" several weeks before being granted benefits every time he loses his position. It is, however, a step in the direction of providing some security for the unemployed worker. Fortunately laws are not unchangeable so that we may perhaps hope for amendments in the direction of more adequate protection for the worker in the future.

Emily H. Huntington.

UnIVERsity OF CAIIFornia.

51 Cal. Stats. 1935, p. 1234, § 45 .

52 Ibid. p. 1244, § 101. 